\title{
INVESTIGATING STUDENTS' BELIEFS ABOUT LANGUAGE LEARNING
}

\author{
Naomi Boakye \\ University of Pretoria
}

There is widespread current interest in language learning studies regarding the extent to which student beliefs can influence the language learning process. Whilst institutions may set up frameworks to enable students to learn languages successfully, many researchers contend that ultimately it is the belief systems of the students themselves which will contribute most to the final outcome of the teaching process.

This article explores the idea that the language learning process among students is substantially influenced by their beliefs about this process. A questionnaire based on Horwitz's (1987) BALLI instrument was used to assess students' beliefs in terms of language learning, and the issues are discussed within the categories of aptitude, motivation, learning and communication strategies, the nature of learning, and the difficulty of language learning.

The results indicate that the beliefs of the students can have a negative influence on their learning strategies which, in turn, affect the success or otherwise of the language learning process. This article thus concludes with suggestions on how to address the negative mindsets of the students concerned in order to create environments that would be more conducive to achieving positive results.

\section{Keywords}

student beliefs; language learning; language styles; language strategies; at risk students

\section{INTRODUCTION}

In class, we have...students who never speak and others who cannot keep quiet, those who ask for rule after rule and those who abhor listening to rules being given much less studying them. And outside of class from all of these different types, we have heard lengthy explanations, which contain a rationale for each person's own behaviour. (Fanselow, 1987: ix)

Of course, a number of factors influence the outcomes of the language learning process. One of the challenges facing language teachers relates in particular to the extent to which the beliefs of students can influence the efforts put into learning new languages (Horwitz, 1987). This is an important issue for teachers of language, since every teacher would like to obtain maximum results from the efforts exerted specifically to achieve the desired outcomes. Consequently, language teachers must know what beliefs their learners have as well as the 
strategies that they employ in the language learning process. It is evident from Fanselow's observation quoted above that some students prefer pattern drills while others desire free conversation. Besides, there are also students who may want the teacher to correct every mistake they make, while others are reluctant to speak for fear of making mistakes. Learners' beliefs and expectations of language learning may thus enhance or slow down the process. For instance, if beliefs are erroneous (or what Horwitz, 1987: 119 refers to as 'myths'), they may influence language learning strategies negatively, and ultimately the success of the language learning process (Horwitz, 1987; Oxford, 1994; Weideman \& Lepota, 2002). This makes it essential to investigate learners' beliefs in order to gain an insight into their expectations as well as their language learning strategies. The teacher can then consider ways of correcting negative strategies and plan how to address erroneous beliefs, in order to influence the success of the language learning process.

\section{OBJECTIVES}

This article presents the results of an investigation into students' beliefs, drawing comparisons between a similar study in 2002 in the same institution and another study by Horwitz (1987) in the United States. Secondly, it identifies erroneous beliefs and the influence they have on students' language learning strategies. In addition, it suggests some ways in which students and teacher expectations can be harmonised and how erroneous beliefs can be challenged or changed in order to aid, facilitate and enhance the language learning process.

\section{LEARNERS’ BELIEFS AND THE LANGUAGE LEARNING PROCESS}

Research has shown that learners employ different learning styles and strategies during the second language learning process (Horwitz, 1987: 119). For example, some students have analytical, field-independent personalities while others exhibit more communicative, interactive field-dependent styles (Cook, 1991:87; Brown, 1994:107; Oxford, 2002: 127). In other words, some learners perceive their learning items as specific items; others perceive their learning items as a unified whole. The analytic, field independent styled students prefer rule learning, dissecting words and phrases and contrasting the L1 with the L2. Interactive field dependent students who perceive learning items globally are more likely to employ strategies to find meaning (i.e. guessing, predicting, scanning and paraphrasing) A student's learning style will, invariably, influence his/her approach to language learning. Strategies, on the other hand, are contextualized and culturally shaped and constitute the learner's approach to language learning. Oxford (1994) refers to them as 'specific actions, behaviours, steps, or techniques that students use in apprehending, internalizing, and using the L2'.

Both styles and strategies are influenced by the learner's beliefs about learning a language, and can have a strong impact on the success of language learning (Horwitz, 1987:120; Tarone \& Yule, 1989: 719; Brown, 1994: 103). According to Horwitz (1987:120), the belief students have about language learning can affect how they go about doing it. For example, if students believe that they should always get it right, then contrary to research on language learning, they will not speak until they are absolutely sure it is right. As Tarone and Yule (1989: 7) explain, learners who are concerned with grammatical correctness may become hesitant, lack fluency, and consequently, sacrifice communicative effectiveness in using the language, in their attempt to achieve formal accuracy. 
Language learning styles are not easy to manipulate because they are linked to learners' individual personalities. Strategies, on the other hand, can be influenced and channeled into the right direction to promote and enhance language learning. Oxford (1994) argues that '... appropriate language learning strategies', what I shall call positive strategies, 'often result in improved proficiency or achievement'. There are a number of studies which have shown the effectiveness of positive strategies on language development and proficiency (e.g. Horwitz, 1987; Wenden, 1987; O’Malley \& Chamot, 1990; Nunan, 2002).

Oxford (1994) explains, in line with Rubin (1975), that successful L2 learners 'are willing and accurate guesses; have a strong drive to communicate; are often uninhibited; are willing to make mistakes; focus on form by looking for patterns and analyzing them; take advantage of all practice opportunities; monitor their speech as well as that of others; and pay attention to meaning'. As Brown (1994:124) argues, teaching learners how to learn is crucial. Because of the close connection between students' beliefs and the language strategies they use, a first step would be to identify these beliefs. As Tarone and Yule (1989:04) put it:

... identifying what the students need to know... and gaining insight into how the students perceive their own abilities - far from being the purview of the expert outsider - are at the very heart of the successful classroom teacher's activities in second and foreign language instruction.

Raising students' consciousness of their erroneous beliefs and helping them recognise the power of consciously using language learning strategies could bring them closer to being 'good language learners'.

In addition to being a powerful influence on learner strategies, learners' beliefs could clash with the teacher's and cause conflict in the classroom. As Brown (1994: 124) points out, learners often bring with them certain preconceived notions of what and how language learning should be. If these expectations (which are informed by beliefs) are not in line with what goes on in the classroom, learners might be demoralized or overly anxious. For example, a learner who has a traditional teaching expectation may become anxious or disappointed if put in an interactive situation and made to take responsibility for his/her own learning. Such emotions, may then limit progress and development in language learning instead of promoting it.

Because of his awareness that learners' beliefs influence their language learning, Horwitz (1987:120) developed an instrument (BALLI) to assess students' beliefs about language learning and to discover how students' beliefs influence language learning strategies and ultimately success in language learning. A modification of her instrument (BALLI-M) was used in the South African context by Weideman and Lepota (2002).

The Unit for Academic Literacy at the University of Pretoria has the specific brief of minimising the likelihood of failure of at risk students at the University of Pretoria. These students have been identified by a reliable, standardised placement test as being at risk academically due to their low level of (academic) language proficiency (Van Dyk \& Weideman, 2004: 01). The Unit offers courses aimed at raising their level of language proficiency. To give students the best chance of success, impediments to academic language development have to be eliminated as far as possible. Hence, beliefs that may hinder that development have to be exposed and possibly changed. This explains why the 2002 study 
was undertaken by Weideman and Lepota as well as the subsequent 2006 study, which is reported in this article.

\section{THE STUDY}

The original instrument developed by Horwitz consisted of 34-likert scale items, which the 2002 study reduced to 25 since certain items were inappropriate for the South African context. The questionnaire (see Appendix) was a seven-point scale that ranged from 'strongly agree' to 'strongly disagree'. The questionnaire was incorporated into the first term tasks that student had to do from their course book, (Weideman, 2003). Respondents were first-year students from various faculties who had been identified as being at risk academically and were therefore undertaking the academic literacy course. The previous study in 2002 was conducted in the second term but was switched to the first term in this study (2006) to allow adequate time to deal with erroneous beliefs should they be present.

\section{FINDINGS}

The findings were interpreted using the five categories classified by Horwitz and also used in the 2002 study. The statements (see Appendix) were grouped under the five categories listed as follows:

Motivation: statements 1, 6, 11, 15

Aptitude: statements 3, 8, 13, 17, 20

Difficulty of language: statements 4 and 22

Strategies for learning and communication: statements 5, 9, 10, 14, 18, 19, 23, 24, 25

Nature of language learning: statements 2, 7, 12, 16, 21

The instrument used in 2002, the BALLI-M (an adaptation of Horwitz' BALLI instrument; see Appendix) was used for the current study. Findings showed similarities on various categories especially motivation and aptitude. Responses to statements on motivation, and aptitude were very similar to the two previous studies, as shown in tables one and two.

Table 1: Responses to statements on motivation for three surveys

Item
\begin{tabular}{|l|l|l|l|l|}
\multicolumn{1}{|c}{ Statement } & $\mathbf{2 0 0 6}$ & $\mathbf{2 0 0 2}$ & $\mathbf{1 9 8 7}$ \\
\hline 1 & $\begin{array}{l}\text { I would like to learn English so that I } \\
\text { can study successfully. }\end{array}$ & $94 \%$ & $90 \%$ & - \\
\hline 6 & $\begin{array}{l}\text { English is a language of opportunity } \\
\text { and employment. }\end{array}$ & $88 \%$ & $86 \%$ & $78 \%$ \\
\hline 11 & $\begin{array}{l}\text { If I improve my English, I will have a } \\
\text { better chance of finding a good job. }\end{array}$ & $80 \%$ & $84 \%$ & $78 \%$ \\
\hline 15 & $\begin{array}{l}\text { I want to learn to speak, read and write } \\
\text { English very well. }\end{array}$ & $93 \%$ & $96 \%$ & $91 \%$ \\
\hline
\end{tabular}


Table 2: Responses to statements on aptitude for three surveys

Item
\begin{tabular}{|l|l|l|l|l|}
\hline \multicolumn{1}{|c}{ Statement } & \multicolumn{2}{c|}{ Percentage agreeing } \\
\hline 3 & $\begin{array}{l}\text { I believe that some people have a } \\
\text { special ability for learning languages. }\end{array}$ & $59 \%$ & $73 \%$ & $81 \%$ \\
\hline 8 & $\begin{array}{l}\text { It is easier for children than for adults to } \\
\text { learn English as another language. }\end{array}$ & $75 \%$ & $78 \%$ & 845 \\
\hline 13 & $\begin{array}{l}\text { People who are good at mathematics are } \\
\text { not good at languages. }\end{array}$ & $27 \%$ & $22 \%$ & $0 \%$ \\
\hline 17 & $\begin{array}{l}\text { Women are better than men at learning } \\
\text { languages. }\end{array}$ & $25 \%$ & $20 \%$ & $19 \%$ \\
\hline 20 & $\begin{array}{l}\text { Everyone can learn to use English as a } \\
\text { second/foreign language. }\end{array}$ & $83 \%$ & $91 \%$ & $85 \%$ \\
\hline
\end{tabular}

In addition, responses to statement 23 ('It is important for improving my English that the teacher requires me to repeat a lot'), and 25 ('I like to have the teacher correct every error I make.') showed that learners' beliefs might clash with their teacher's. Furthermore, responses showed that beliefs may affect strategies to impede or enhance language learning. The following responses show probable impediments or enhancements to language learning.

Table 3: Responses showing impediments or enhancement to language learning.

\begin{tabular}{|c|c|c|c|}
\hline Iten & Statement & \multicolumn{2}{|c|}{$\%$ agreeing Feature } \\
\hline 3 & Some people have an ability to learn new languages. & $59 \%$ & impediment \\
\hline 14 & I feel timid when speaking English. & $24 \%$ & impediment \\
\hline 16 & Learning English is translating from my mother tongue. & $57 \%$ & impediment \\
\hline 9 & I enjoy practising English with people I meet. & $80 \%$ & enhancement \\
\hline 10 & It's okay to guess if you don't know a word in English. & $48 \%$ & enhancement \\
\hline
\end{tabular}

The findings are discussed in detail under the categories listed above (i.e. motivation, aptitude, difficulty of language, strategies of learning and nature of language learning).

\section{Motivation}

The results of the present study (2006) were highly congruent with the 2002 study. For the statements that probed motivation towards language learning $(1,6,11$, and 15) there were great similarities in the results of all three studies.

Responses to statements 1, 6, 11, and 15 showed high motivation among learners.

For statement 1 ('I would like to learn English so that I can study successfully'), the majority of the students agreed (90\% agreeing strongly or fairly strongly). Responses to statement 6 ('English is a language of opportunity and employment') also showed a high level of agreement. Seventy-nine percent agreed strongly or fairly strongly. Responses to statement 11 ('If I improve my English, I will have a better chance to find a good job') and 15 ('I want to learn to speak, read and write English very well') showed that students overwhelmingly 
agree. Eighty per cent agreed with statement 11 and $91 \%$ agreed with statement 15 (90\% agreeing strongly or fairly strongly).

Results of the 2002 study also showed high motivation among students. The 'agree' option was chosen by $90 \%$ in the case of statement $1,86 \%$ in the case of statement $6 ; 84 \%$ in the case of statement $11,96 \%$ in the case of statement 15 . When these two sets of results obtained within a four year interval are compared with that of Horwitz' study of an entirely different group of learners, culturally and contextually, one observes great similarities. The graph below illustrates these similarities.

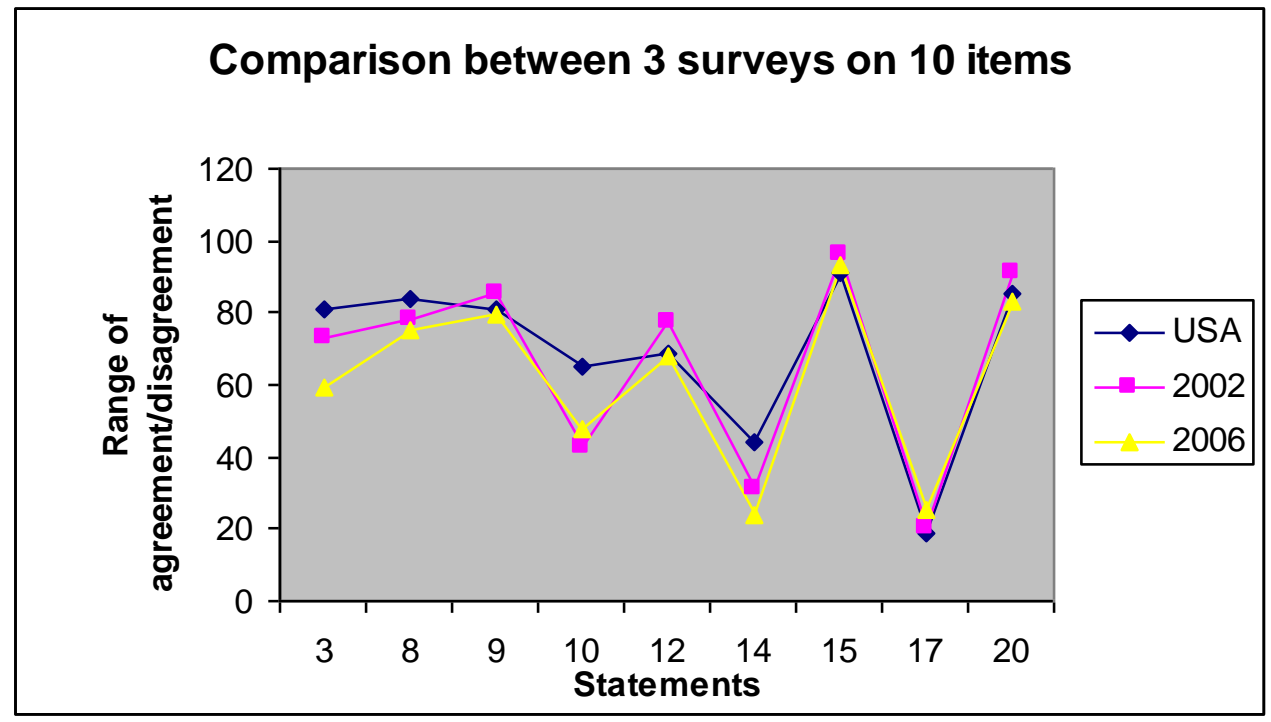

\section{Figure 1}

Though the number of responses is fairly limited, $(n=155$ for this study) one may generalise that motivation among English additional language learners at tertiary level is quite high. This is encouraging as high motivation is one of the factors that aid successful language learning (Ellis, 1985:118; Oxford, 1994). For instance, high motivation has been linked to the use of multiple strategies (O’Malley \& Chamot, 1990; Oxford, 1994) which, according to Oxford (1994), often have more impact on the success of language learning, than single strategies which are used by less motivated learners. In addition, instrumental motivation, which this group of students seems to have in abundance, is an effective indicator of successful second language learning (Ellis, 1985: 119). As Cook (1991:75) puts it, high motivation will propel a student to strive for and gain success in L2 learning.

\section{Aptitude}

Responses to certain aptitude statements also showed congruence with the 2002 study, and with Horwitz's original study. The aptitude statements yielded the following results. Responses to statement 3 ('I believe that some people have a special ability for learning new languages') were varied, with a mean of 4.74 and a standard deviation of 1.98. Fifty-nine percent $(59 \%)$ of the students agreed with the statement, but $14 \%$ indicated that they were uncertain. This showed less certainty among the students. Further evidence of this is provided by the $27 \%$ who disagreed. Although the students' responses to statement 3 were varied, the results are more encouraging than those for the 2002 group, which had $73 \%$ agreeing that 'some people have a special ability to learn new languages'. 
Responding to whether children find it easier to learn a language, $37 \%$ of the students strongly agreed. Overall, although $75 \%$ agreed, some uncertainty on the issue is shown in the $9 \%$ who indicated uncertainty and the $16 \%$ who disagreed. The fact that more than $50 \%$ agreed with the view requires further investigation. Perhaps one cannot say that the view is completely erroneous, but for learners who are enrolled in a course in developing academic English language proficiency the responses reflect an attitude that could have a negative impact on their learning. If students believe that additional language learning is easier for children, they may perceive the task as difficult and success as unattainable.

The responses to statement 5 are similar to those of 2002, indicating that these views are common and may be general views among language learners. Responses to the statement, 'You shouldn't say anything in English until you can say it correctly', showed that only 13\% of the students agreed. Similarly, in the 2002 study only 15 percent of the students in the group agreed. This suggests that students are generally prepared to speak without fear of making mistakes. This is a positive attitude, and is in line with the communicative approach to language teaching and the task-based language teaching that they are exposed to on this course (Weideman, 2003). Research has shown that language learning is more successful if learners interact and communicate freely without any fear of making mistakes, but instead are able to laugh at their mistakes (Cook, 1991; Brown, 1994:114; Oxford, 1994)

Statement 13 comprises a popular yet erroneous belief (i.e. 'People who are good at mathematics are not good at languages'). Responses to this statement were encouraging, as most of the students dismissed the idea that those who are good at mathematics are not good at language learning. Sixty-seven per cent of the students disagreed, which is close to the $66 \%$ of the students who disagreed in 2002. Given that most of the students do not agree that mathematicians are not good language learners, one would expect the views expressed on statement 20 ('Everyone can learn to use English as a second/foreign language') to be positive. Indeed they were. A clear majority (83\%) agreed with the statement. This is encouraging, as it implies that they too can learn a language.

Students' responses to statement 3 were very interesting. Having disagreed with statement 13 ('People who are good at mathematics are not good at language learning') and having overwhelmingly agreed with statement 20 ('Everyone can learn to use English as a second / foreign language') they agreed (59\%) with statement 3 ('Some people have special ability to learn new languages') which contradicts statements 13 and 20. It is surprising that according to this group of students everyone can use English as a second language, yet some people have a special ability to learn new languages. The contradictory responses given to statements 3 and 20 were evident also in the 2002 study and the 1987 study by Horwitz in the United States. The table below illustrates the contradictory responses.

Table 4: Results of three surveys on student agreement to statements 3 and 20

Statements 3 and 20: 2006
\begin{tabular}{|l|l|l|l|}
\hline $\begin{array}{l}\text { Some people have a } \\
\text { special ability to } \\
\text { learn new languages }\end{array}$ & $59 \%$ & $73 \%$ & $81 \%$ \\
\hline $\begin{array}{l}\text { Everyone can learn } \\
\text { to use English as a } \\
\text { second language }\end{array}$ & $83 \%$ & $91 \%$ & $85 \%$ \\
\hline
\end{tabular}


In light of these apparent contradictions in the previous studies, one is encouraged by the low percentages for statement 3 in the current study. This shows that, despite the contradiction, most students believe that everyone can learn to use English as a second language. This indicates that they believe that they too can be successful at language learning.

\section{Difficulty of language learning: Statements 4 and 22}

In addition to the positive belief that everyone can learn to use English as a second or foreign language (statement 20), there were clear indications that a substantial body of students do not attach much difficulty to learning English. In response to statement 22 ('English is one of the most difficult languages to learn if it is not your first language') more than $50 \%$ of the students disagreed. Only a small minority (26\%) agreed that it is a difficult language. This group of students might give up too readily on class tasks and exercises that could develop their (academic) language proficiency.

With regards to statement 4, ('I will be able to learn English very well'), 95\% of the students agree, $88 \%$ agreeing strongly or fairly strongly. This ties in with the high motivation shown in their responses to statements 1, 6,11 and 15. It is good to know that most of the students in this group do not think English is a difficult language. In other words, they perceive success in language learning as achievable. This perception, of course, eases the teacher's task.

Language learning and communication strategies: Statements 5, 9, 10, 14, 18, 19, 23, 24, and 25

Statements pertaining to language learning and communication strategies probed students' language learning strategies. Responses to statement 9 ('I enjoy practising English with people I meet, whenever possible') showed that $80 \%$ of the students agreed. The results tie in with the high levels of motivation shown in questions 1, 6, 11, and 15. In other words, motivation is channelled into interest in using the language. This is a very positive response, especially since a clear majority stated that they find it important to use the English language outside class (statement 19). Eighty-two per cent (82\%) agreed that it is important to create opportunities to use the language outside class. This shows that students are willing to take responsibility for their own learning. Taking language learning outside the classroom is a positive step towards successful language learning. The characteristics of Good Language Learners (GLL) as described by Rubin and Thompson (1982) includes learners finding their own way, taking charge of their learning, and making their own opportunities for practice in using the language inside and outside the classroom. However, students' responses to statement 10, ("It is okay to guess if you do not know an English word") were disappointing. The students in the sample were almost equally divided on the issue. Forty-eight percent $(48 \%)$ of the students agreed whereas $41 \%$ disagreed. Their reluctance to guess can be perceived as a 'negative strategy'. Successful learners are willing to make intelligent guesses (Brown, 1994:114; Oxford, 1994). In this case then, direction should be given. Investigations have shown that good results are produced by teaching and directing learning strategies (Oxford, 1994).

In relation to responses to statements 10 and14 students produced varied responses. However, responses to statement 14 were more encouraging. Sixty per cent of the students disagreed, whereas only $24 \%$ agreed that they feel timid. The fact that the group of students in the study were not as definite about their feelings is shown in the $16 \%$ who were uncertain. 
Table 5

Statement 14: I feel timid when speaking English with other people.

\begin{tabular}{|l|l|} 
Responses & percentages \\
\hline Agree & $24 \%$ \\
\hline Uncertain & $16 \%$ \\
\hline Disagree & $60 \%$ \\
\hline
\end{tabular}

The responses were once again congruent with those of the 2002 study. The similarities between the two sets of results are very strong as shown in the table below.

Table 6: Comparison between two surveys (2002 and 2006) on students' responses to Statement 14: I feel timid when speaking English

\begin{tabular}{|c|c|c|}
\hline Responses & $2006 n=155$ & $2002 n=80$ \\
\hline Agree & $24 \%$ & $31 \%$ \\
\hline Uncertain & $16 \%$ & $9 \%$ \\
\hline Disagree & $60 \%$ & $60 \%$ \\
\hline
\end{tabular}

Although overall most students indicated that they did not feel timid when speaking English, the few who acknowledged feeling timid, may be reluctant to speak and this may slow the language learning process. This poses a challenge to the teacher. He or she would have to devise various methods and strategies of language teaching that would help students to overcome their timidity, and to communicate in and out of class. For instance, in addition to increasing group and teamwork, the teacher would have to create a relaxed teaching and learning environment that would enable students to overcome their timidity.

The concern with students learning and communication strategies is even deeper when one considers responses to statement 18 . Half of the students in this group agreed that if permitted to make errors they would encounter difficulties later. To challenge this view, an explanation of interlanguage errors and the progression to target language forms (Kilfoil \& van der Walt, 1997: 93; Ellis, 1985: 47/48; Cook, 1993: 20) could be discussed with students.

In the light of the responses to statement 18 , one is not surprised that $80 \%$ of the students expect their teachers to correct every error they make (statement 25). Also, most of the students (50\%) believe that repetition will improve their English language proficiency (statement 23). These views indicate that learners' expectations may clash with the teacher's instructional style. One way of aligning learners' expectations with the teacher's instructional style is to discuss the issues in relation to successful language learning and the good language learner as characterised by Naiman, Frolich, Stern and Todesco (1978: 12); and Rubin and Thompson (1982: 2).

Only a few students (20\%) agreed with statement 5 ('You should not say anything in English until you could say it correctly'). Responses to statement 24 show that $65 \%$ of the students agreed that they rehearsed what they want to say before they say it. The advantage of this strategy is that students are able to monitor correct forms before speaking, which according to Cook (1991:28) aids and enhances production. 


\section{Nature of language learning: Statements 2, 7, 12, 16, and 21}

Statements 2, 7, and 21, were based on the important aspects of language learning. (i.e. grammar, vocabulary and communication). Students' responses showed apparent contradictions. Most of the students (73\%) stated that grammar is the most important part of language learning, and still believed ( $86 \%$ of them) that vocabulary is the most important aspect of language learning. They overwhelmingly (82\%) also indicated that communication is the most important part of language learning. These contradictory or varying views could clash with the teacher's teaching style. If students expect grammar and vocabulary and the teacher focuses on improving communication skills, students could get bored and frustrated. In addition, the learner who feels that hard-core grammar instruction will aid his/her language learning will be frustrated by teaching which emphasises vocabulary development and or communication skills. It is important that the teacher is aware of learners' expectations in order to allow classroom instruction that caters for all types of language learning, while emphasising development of communication strategies and enhancement of communication skills.

Responses to statement 16 ('The most important part of learning a language is learning how to translate from my mother tongue') were varied. However, more students agreed (57\%) than those who disagreed (31\%). Again, a class discussion could indicate the consequence of this erroneous belief.

\section{DISCUSSION}

As indicated earlier, the results of the study were largely similar to the 2002 study. Both groups of students were highly motivated. Responses from students within the two groups show that indeed, some of our learners' beliefs may clash with the teacher's instructional style. For example, a high percentage of students from the two groups, expect the teacher to correct every mistake they make, and to engage them in constant repetition. Responses to statement 7 show that despite the introduction of current approaches to language teaching, students continue to view grammar teaching as most important in language learning. This suggests a desire for outmoded methods such as audiolingualism (drill), and frequent error correction.

In addition, results show that learners' beliefs do affect strategies to enhance or impede L2 learning. Most of the students agreed that some people have a special ability for learning new languages (statement 3). In other words, they attribute successful language learning to certain groups of people. The majority of students $(75 \%)$ believed that children find language learning easier. This belief was shared by most of the students (78\%) in the 2002 study. Unfortunately, such a belief may impede L2 learning, as students may easily give up on the learning process if difficulties are encountered. A significant percentage (24\%) of students agreed about feeling timid when speaking English (Table 5). The responses to this statement were congruent with the responses obtained from the 2002 study as shown in Table 6 above. Furthermore, the majority of the students agreed about translating from their mother-tongue into the target language before speaking: a strategy which slows down and impedes L2 learning (see Krashen, 1985).

Having a class discussion with students seems to be one effective solution (Horwitz, 1987; Tarone \& Yule, 1989; Brown, 1994; Weideman \& Lepota, 2002). Students may not be aware 
that their choice of strategies may impede their language learning. Discussions of erroneous beliefs would bring awareness to students and provide them with a better understanding of the detrimental effects of their beliefs. The profile of the GLL provided by Naiman et al. (1978: 12) and Rubin and Thompson (1982: 2) could be discussed to give learners a yardstick with which to measure or compare their own learning strategies. They could also be offered the following advice:

1. Find a learning style that suits you.

2. Involve yourself in the language learning process.

3. Develop an awareness of language both as system and as communication.

4. Pay constant attention to expanding your language.

5. Develop the L2 as a separate system.

6. Take into account the demands that L2 learning poses.

(Cook 1991:78-81)

Hopefully, by adopting this approach, the teacher would be able to direct learners' beliefs towards strategies of successful language learning. Brown (1994:124) however, points out that this may not be an easy process and teachers should not expect instant success. For those whose beliefs clash with the teacher's (for instance, the learner who desires rules) the teacher could, on occasion, incorporate grammar teaching while pursuing the communicative approach. Conscious learning of grammar rules according to Ellis (1985: 261) can serve as monitor, or as Tarone \& Yule (1989: 6) explain, could later become automated processes in language use. However, I suggest that where grammar teaching takes the form of rules and completion of discrete point tasks, it be kept to the minimum. If possible it should be done through e-learning to introduce variety and maintain a high level of interest.

For those with expectations of formal traditional teaching, Tarone \& Yule (1989:9) suggest three approaches. First, if the group is small, the teacher could ignore the expectation, and hope students will see benefits of the communicative approach. Secondly, if the expectation is shared by the majority, the teacher could abandon his/her approach and meet learners' expectations. The third, which seems to be more harmonious, is what is referred to as channel 'em (Tarone \& Yule, 1989:9). They see this as a compromise in which the teacher and students can both fulfil their expectations. In practice, this may involve starting a class in a more traditional method and ending in a communicative-interactive style, or beginning with communication tasks and ending with a consideration of grammar forms. Such techniques, it is believed, will reduce clashes and conflicts between teacher and students' expectations and hopefully promote a conducive environment for successful language learning (Tarone and Yule 1989:10).

The teaching strategies employed in response to the study yielded beneficial results. Class discussions on learner beliefs and learning strategies brought awareness to students. Although students initially argued strongly for what they believed in, further explanations and discussions brought awareness and gave students insight into the negative influence that some of their beliefs have on language learning. As a result students began to display positive attitudes towards the course - as was revealed through informal discussions outside class. Coupled with these positive attitudes that students had developed, was their willingness to change erroneous beliefs and their corresponding negative strategies (e.g. translating from mother tongue into English before speaking or writing). 


\section{CONCLUSION}

No matter what a teacher does in the classroom, it is the learner's involvement that matters. In other words, the learners' beliefs and ultimately their strategies of language learning largely influence the language learning process. If directed correctly, the beliefs will enable the learner to use appropriate strategies to develop L2 learning successfully. Beliefs could be accessed through the BALLI-M. To strengthen the results focus group interviews, which the author hopes to undertake in a subsequent study, could be included.

I hope that the suggestions given above (i.e. discussion of erroneous beliefs, awareness of GLL strategies, and use of techniques to harmonise student and teacher expectations in sensitive ways), will influence strategies positively. In conclusion, I would recommend that whatever tasks students are made to perform should be aimed at developing metacognitive and cognitive strategies, which should lead to the enhancement of their ability to perform tasks that are crucial in developing academic language proficiency.

\section{REFERENCES}

BROWN, DH. 1994. Principles of language learning and teaching. Englewood cliffs: Prentice Hall.

COOK, V. 1991. Second language learning and language teaching. New York: Edward Arnold.

COOK, V. 1993. Linguistics and second language acquisition. London: Macmillan Press.

ELLIS, R. 1985. Understanding second language acquisition. Oxford: OUP.

FANSELOW, JF. 1987. Foreword. In Wenden, A \& J Rubin (Eds), Learner strategies in language learning. Englewood Cliffs: NJ Prentice-Hall. ix-X.

HORWITZ, E. 1987. Surveying student beliefs about language learning. In Wenden, A \& J Rubin (Eds), Learner strategies in language learning. Englewood Cliffs: NJ PrenticeHall. 119-129.

KILFOIL, WR. \& C VAN DER WALT. 1997. Learn 2 teach: English language teaching in a Multilingual context. Pretoria: van Schaik Publishers.

KRASHEN, S. 1985. The input hypothesis. Harlow: Longman.

NAIMAN, N, M FROHLICH, HH STERN, \& A TODESCO. 1978. The good language learner. Toronto: Ontario Institute for Studies in Education.

NUNAN, D. 2002. Learner strategy training in the classroom: An action research study. In Richards, JC \& WA Renandya. Methodology in language teaching: An anthology of current practice. Cambridge: Cambridge University Press. 133-143.

O'MALLEY, JM \& AU CHAMOT. 1990. Learning strategies in second language acquisition. Cambridge: CUP. 
OXFORD, R. 1994. Language learning strategies. http://www.cal.org/resources/digest/oxford01.html [Accessed 4 July 2006].

OXFORD, R. 2002. Language learning strategies in a nutshell: Update and ESL suggestions. In Richards, JC \& WA Renandya. Methodology in language teaching: An anthology of current practice. Cambridge: Cambridge University Press. 124-132.

RUBIN, J. 1975. What the 'good language learner can teach us'. TESOL Quarterly, 9: 41-51.

RUBIN, J \& I THOMPSON. 1982. How to be a more successful language learner. Boston: Heinle and Heinle Publishers.

TARONE, E. \& G YULE. 1989. Focus on the language learner. Oxford: OUP.

VAN DYK, T \& A WEIDEMAN. 2004. Switching constructs: on the selection of an appropriate blueprint for academic literacy assessment. SAALT Journal for language teaching. 38(1):1-13.

WEIDEMAN, A. 2003. Academic literacy: Prepare to learn. Pretoria: Van Schaik.

WEIDEMAN, A. \& B LEPOTA. 2002. Our ways of learning language. SAALT Journal for Language Teaching, 36(3\&4): 206-219.

WENDEN, A. 1987. How to be a successful language learner: Insights and prescriptions from L2 learners. In Wenden, A \& J Rubin (Eds), Learner strategies in language learning. Englewood Cliffs, N. J. Prentice-Hall. 103-118.

\section{BIOGRAPHIC NOTE}

Naomi Boakye is a lecturer in the Unit for Academic Literacy at the University of Pretoria E-mail: Naomi.boakye@up.ac.za. 


\section{APPENDIX \\ Questionnaire}

Here is a questionnaire that you have to complete in order to evaluate your own language learning style and your beliefs about language learning. For each statement, you have to chose the response that you believe is true for you, by marking it clearly on the scale provided(strongly disagree-disagree fairly strongly-disagree-uncertain-agree-agree fairly strongly- strongly agree)

1. I would like to learn English so that I can study successfully.

2. The most important part of learning another language is learning its vocabulary.

3. I believe that some people have a special ability for learning new languages.

4. I believe that I will learn to read, write and speak English very well.

5. You shouldn't say anything in English until you can say it correctly.

6. English is a language of opportunity and employment.

7. The most important part of learning another language is learning its grammar.

8. It is easier for children than for adults to learn English as another language.

9. I enjoy practising English with people I meet, whenever possible.

10. It's okay to guess if you don't know a word in English.

11. If I improve my English, I will have a better chance of finding a good job.

12. Learning English is different from learning other academic subjects.

13. People who are good at mathematics are not good at languages.

14. I feel timid when speaking English with other people.

15. I want to learn to speak, read and write English very well.

16. The most important part of learning English is learning how to translate from my mother tongue.

17. Women are better than men at learning languages.

18. If beginner students are permitted to make errors in English, it will be difficult for them to speak correctly later on.

19. I find it important to create opportunities for myself to use English outside of class.

20. Everyone can learn to use English as a second/ foreign language.

21. The most important part of learning English is to become fluent in communicating.

22. English is one of the most difficult languages to learn for someone who does not have it as a first language.

23. It is important for improving my English that the teacher requires me to repeat a lot.

24. I like to rehearse in my mind what I want to say before I speak or write something in English

25. I like to have the teacher correct every error I make, so that I don't learn bad habits. 